\title{
A Review on the Recent Quality-of-services (QoS) Issues in MANET
}

\author{
Lalit Johari \\ Research Scholar \\ School of Computer Applications \\ IFTM University Moradabad
}

\author{
Rahul Kumar Mishra, PhD \\ Professor \\ School of Computer Applications \\ IFTM University Moradabad
}

\begin{abstract}
The purpose of this paper is to carry out study on delay minimization techniques of data transmission, which is a major Quality-of-service (QoS) parameter in Mobile ad-hoc network (MANET). Various algorithms that are given in the study of previous investigators have been considered and analyzed and a tabulated summary work has been carried out. Related works shows the various previous works done on QoS service parameter delay. On various conclusions, this paper focuses on end-to-end delay and its effective factors so that an efficient data transmission is achieved.
\end{abstract}

\section{General Terms}

Quality of services in MANET

\section{Keywords}

Quality of services (QoS), Route Optimization, end-to-end delay

\section{INTRODUCTION}

Mobile ad-hoc network is a combination of three words, Mobile means 'Mobility', Ad-Hoc means 'temporary' and networks means 'Collection of communication nodes' [1]. So MANET is an autonomous collection of communication nodes that does not have any rigid infrastructure and preconsidered structure of nodes. Despite the lack of core centralized administration, these nodes can keep in touch with one another via radio waves to exchange information and can constitute any network topology.

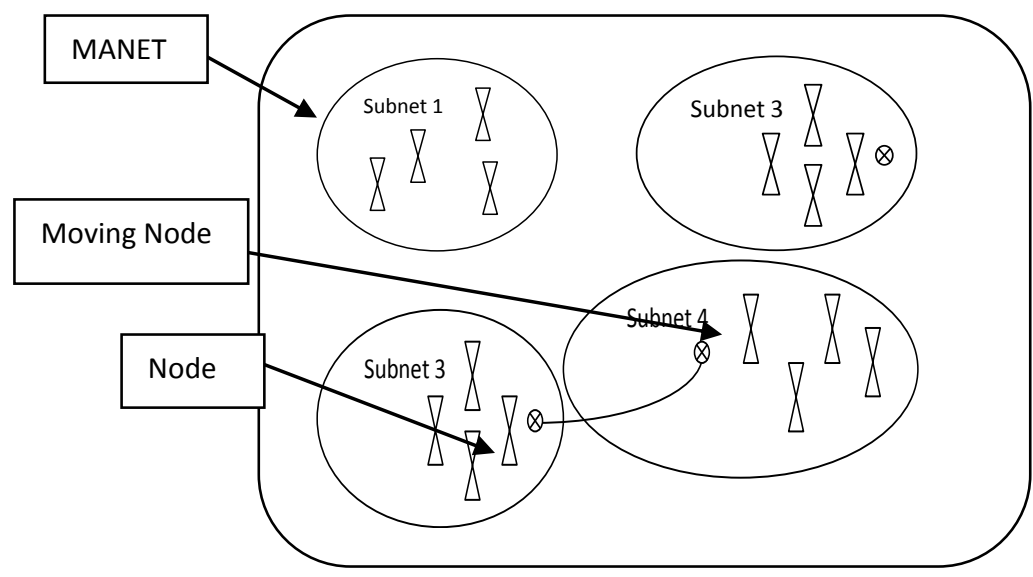

Figure 1: Mobile ad-hoc Network Topology

Figure 1 shows a simple ad-hoc network with four subnets, each subnet has different nodes. A moving node from subnet 3 range to subnet 4 range. In this manner different network topologies made and any node can be used to forward packets from source node to destination node. Direct communication between these nodes takes place if they are within the range of radio transmission [2]. These nodes together form an ad-hoc network.

Mobile ad-hoc networks (MANETs) are useful in those environments where fixed wired infrastructure cannot use such as inimical environment monitoring, disaster rescue environment, and battlefield communications. In these environments reliable data transmission required. Transport control protocol (TCP) remains to use provide reliable data delivery for communication not only within MANET but also across MANETs and Internet [3]. MANET also has lower bandwidth than that of wired network because it is operating on batteries, so its operation must be energy efficient to maximize the life of the node.
The objective of this paper to present a work done in the field of end-to-end delay which is a major QoS parameter. In the field of QoS in MANET previously done research work mentioned in related work and with the help of table summarized work is achieved which is done previously to find minimum end-to-end delay. This paper is divided into two parts section I gives the overview about routing and routing protocol along with Quality of service work emphasizing on QoS parameters. Section II discusses the related work done in the last one decade and tabulated form shows the comparisons of various solutions done for end-toend delay.

\section{ROUTING AND ROUTING PROTOCOLS}

In MANET, all nodes are not in the transmission range of each other so nodes are required to forward network traffic on behalf of other nodes. This process is known as routing. Routing in MANET is achieved by routing protocols. Routing is used to transmit a packet from source to destination in a network. Routing protocols are classified as in figure 2. 
Proactive routing protocols maintain a table at each node this table is known as the routing table. Routing table store the information of other nodes in the network. Whenever a node wants to search another node to forward the data packet, nodes get the information from the routing table. Routing table gets updated periodically [4]. Some important proactive routing protocols are Optimized link state routing (OLSR), Wireless routing protocol (WRP), Destination sequenced Distance Vector Routing (DSDV) etc. In contrast to proactive routing protocols, reactive routing protocols determine the route and establish the connection when a source node wants to send the data packet to a destination node. To determine the route, route request packets are flooded to network [5]. Some important proactive routing protocols are Dynamic source routing (DSR), Ad-hoc on demand vector routing (AODV), Temporally Ordered Routing Algorithm (TORA) etc.

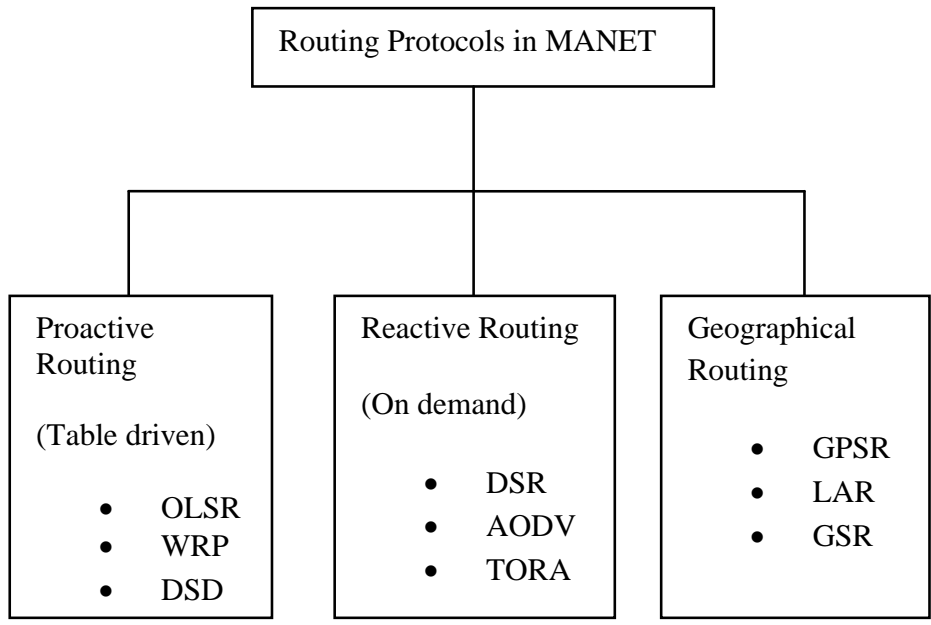

Figure 2: Classification of Routing Protocols

Geographical routing protocols use information which sense from the location to optimize the route from source to destination. Geographical routing is useful because it eliminates the redundancy between packets coming from many sources. Geographical routing protocols decrease the requirement of maintaining routing table and also eliminate the need for flooding-mechanism to broadcast data and control packets over the entire network for establishing routes between source-destination pair [6].

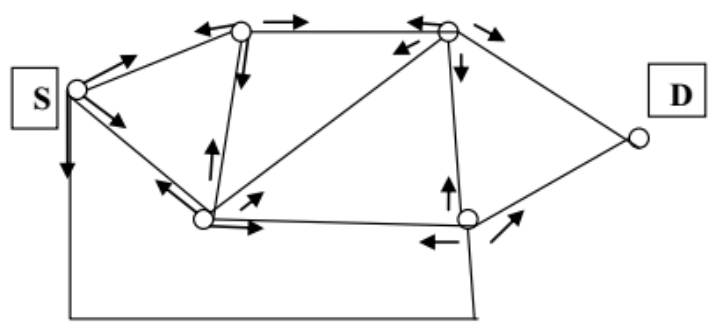

Figure3: Flooding for Route Discovery

Some important proactive routing protocols are Greedy perimeter Stateless routing (GPSR), Location added routing (LAR), geographically source Routing (GSR) etc. The routing protocol should able to different levels of Quality of Services (QoS) to different types of applications as well as users. So in next section, QoS is broadly discussed with different QoS parameters and classify the end-to-end delay.

\section{QUALITY OF SERVICES IN MANET}

The word quality is defined as "the totality of characteristics of an entity that bear on its ability to satisfy stated and implied needs". So Quality of Service (QoS) as "the collective effect of service performance which determine the degree of satisfaction of a user of the service". IETF considers QoS as the ability to segment traffic or differentiate between traffic types in order for the network to treat certain traffic flows differently from others. QoS encompasses both the service categorization and the overall performance of the network for each category.

A QoS is a big factor because it not only considers the forwarding of packets from sender to receiver but also the forwarding of the packet via optimized route. Due to resource constraints and dynamic topology, supporting Quality of Service (QoS) in MANETs is an encouraging task. Qualities of Service (QoS) parameters are mostly bandwidth, delay, jitter, and packet loss. Routing can inform a source node about the bandwidth and QoS accessibility of a destination node [7]. Thus, QoS is an assurance by the system to suit a set of predefined service performance constraints for the user in terms of the end-to-end delay statistics, obtainable bandwidth, a possibility of packet loss, and so on[8]. It is vital that routing protocols include QoS metrics in route finding and maintenance to bear end-to-end QoS. These routing protocols are known as a QoS-aware routing protocol. For QoS-aware routing protocol the basic design issued that are considered in different routing protocols are based on Estimation of Resource, Route Finding, Reservation of Resource , Maintenance of Route, Selection of Route with minimum delay, acknowledgement to deny route requests if bandwidth is not available and Providing feedback to the application about available bandwidth resources or route delay estimation[9].

\section{Table 1. Formula for each QoS Metrics}

\begin{tabular}{|c|c|}
\hline Metrics & Formula \\
\hline Throughput & $\begin{array}{c}\text { No. of packet received/ No. of per } \\
\text { unit time }\end{array}$ \\
\hline $\begin{array}{c}\text { Packet Delivery } \\
\text { Ratio(PDR) }\end{array}$ & $\begin{array}{c}\text { No. of packet received/ No. of } \\
\text { packet sent }\end{array}$ \\
\hline Jitter & {$[($ PA+1)-(PS+1))-((PA)-(PS))]/N-1 } \\
\hline Packet Loss & $\begin{array}{c}\text { No. of packet sent- No. of packet } \\
\text { received }\end{array}$ \\
\hline \multicolumn{2}{|c|}{ PA=Packet Arrival, PS=Packet Start } \\
\hline
\end{tabular}

Quality of Service needs to consider several criteria's that could affect the quality of the chosen path in packet forwarding process. The most appropriate method to find the best path from sender to receiver by routing protocol is to get the shortest path that can achieve with the help of minimum hop-count value but such a selected path not always the optimum path to deliver data need high QoS metrics[10]. Thus, the routing protocol has to consider another method or way to select the path.

Each and every application has different requirements in terms of QoS. The services required by different applications associated with different applications QoS parameters. For example multimedia applications QoS parameters are totally different with military applications. For multimedia applications key QoS parameters are bandwidth requirement, time, and probability of packet loss, jitter, power requirement, 
Route acquisition Delay, Communication Overhead, Scalability, on the other hand military applications have security related QoS parameters. For emergency applications such as search and rescue operations have QoS parameter which is only availability of network.

The delay is the total time experienced by a packet to go across the network from the starting-place to the goal. At the network layer, the end-to-end packet delay is the summation of processing delay, transmission delay, queuing delay, and propagation delay. The end-to-end delay of a path is the summation of the node delay at each node and the link delay at each link on the path [11].

End-to-end delay $=$ Node Delay + Link Delay

Node delay which is at each node includes the protocol processing time, Queuing Delay at any node and MAC delay. On the other hand Link delay which is at each link on the path includes the propagation delay.

The packet end-to-end delay is the time taken by data packet to transmit across the network from source to destination. It includes transmission wait, propagation wait, processing wait and queuing wait [12].

The end-to-end delay is the time needed to traverse from the source node to the destination node in a network. End-to-end delay assesses the ability of the routing protocols in terms of use- efficiency of the network resources. End-to-end delay can be calculated as follows:

\section{End to End Delay $D(e-e)=D(t s)+D(p g)+D(p c)+D(q u)$}

Transmission delay: The total time devoted to come out all of the data packets bits against the link constitutes is known as the transmission delay. This includes the addition of existing router information and time for transfer the acknowledgement signal to the source router on successful transmission of data.

Transmission delay $\mathrm{D}(\mathrm{ts})=$ Packet size/ Data rate

Propagation delay: The time devoted by the data packets to travel in air from one router to another router is called as propagation delay. Its value is usually in milliseconds. And it depends on the distance and mobility of the nodes.

Propagation delay $\mathrm{D}(\mathrm{pg})=$ Total geometric distance of the route/ Link speed

Processing delay: The time taken in examining the packet header and examine where it should be directed is termed as processing delay. If the packet is to be aimed at the node then it is queued inside the nodal buffer. This delay is in microseconds $(\mu \mathrm{s})$.Data packet will not be processed, unless and until all of the packet's bits were not received.

Queuing delay: The time taken for being in the queue waiting till the data packets arrived before gets transmitted, forms the queuing delay. Queuing delay is zero for a packet arriving at an empty buffer, since it is directed to transmit over the link. For the two packets arriving at an empty buffer third delay is equal to transmission delay of the first packet arrived and the Nth packet will have (N-1) times the transmission delay.

Queuing delay $\mathrm{D}(\mathrm{qu})=$ Transmission delay $(\mathrm{N}(\mathrm{N}-1)) / 2$

\section{RELATED WORK}

Many scheme and models discuss quality-of-service (QoS) on the basis of mobile nodes that considered the link quality in their designs and architectures. A QoS is a big factor because it not only considers the forwarding of packets from sender to receiver but also the forwarding of the packet via optimized route. Typical QoS parameter includes available bandwidth, packet loss rate, estimated delay, packet jitter, hop count and path reliability.

In the year 2006, author M. Shahram and B. Saeed has proposed a Framework for providing QoS routing in MANETs and concentrate that QoS is a guarantee over the network to provide a set of planned service execution constraints for the user in terms of the end-to-end delay statistics, available bandwidth, probability of packet loss, and others [13].In the same manner, in the year 2012 author Parimal Kumar Giri suggest different basic design consideration for QoS-aware routing protocol such as Resource Estimation, Route Discovery, Resource Reservation, Route Maintenance, Route Selection, Choosing routes with the largest available bandwidth (or minimum delay)[14][15].

In year 2007, Mario Marchese in QoS over heterogeneous networks says that selecting feasible paths that satisfy various QoS requirements of applications in a network is known as QoS routing [16].

In the year 2010 author G. Santhi says that the QoS provisioning approaches can be broadly classified into two categories, hard QoS, and soft QoS approaches. If QoS requirements of a connection are confirmed to be met for the whole span of the session, the QoS approach is named as hard QoS approach. In MANETS, it is very challenging to provide hard QoS assure to user applications. If the QoS requirements are not guaranteed for the entire session, the QoS approach is termed as soft QoS approach. Thus, QoS guarantees can only be given within certain mathematical bounds. Most of the protocols provide soft QoS guarantees [17].

The majority of conventional solution proposed in the literature focus on providing QoS based on mainly two parameter i.e. throughput and delay. Several models are suggested in literature to achieve high throughput for different kind of routing protocols. In $2015 \mathrm{~K}$. Devarajan and V. Padmathilagam introduces a novel method using Markov chain model in both proactive and reactive routing protocols of MANETs for achieving high throughput[18]. On the other hand the basic way to reduce the delay is to restrict the flooding. In 2003 author Q.Xue discoverer the best route possible in terms of minimum end-to-end delay within the bandwidth guarantee.

In year 2015 author V.princy given an algorithm named SOP which minimizes path discovery delay. In this paper SOP approach include that every node in MANET contains the path discovery information to reach the destination and path discovery delay is reduced [19].

In year 2014 author Prakash B. Khelage suggest another Pseudo code for modified packet reordering (MPR) that works on TCP. This paper presents the description and implementation of RTT based proposal TCP-MPR variant, Attached as transport agent and validated, calculated performance parameters in different networks model using ns2.The algorithm is tested and validated in different network model scenarios and Investigate throughput, delay and packet drop using other TCP variants. Based upon processed results and analysis it showed that, TCP-MPR is giving highest throughput, minimum delay and packet drop compared to all variants [20]. 


\section{COMPARISIONS OF VARIOUS SOLUTIONS DONE FOR DELAY}

There are many research has been done on delay minimization approaches. Here a summary is given in table 2 about those researches which have suggested algorithm/approaches to reduce any kind of delay that is discussed above and finally reduce the end-to-end delay.

Table 2. Various Delay Minimization Approaches

\begin{tabular}{|c|c|c|c|c|c|c|}
\hline S.No. & Paper Name & Year & Worked On & $\begin{array}{l}\text { Algorithm } \\
\text { proposed }\end{array}$ & Type of Delay & Conclusion \\
\hline 1 & $\begin{array}{l}\text { The Message } \\
\text { Delay in Mobile } \\
\text { Ad Hoc } \\
\text { Networks[21] }\end{array}$ & 2005 & $\begin{array}{l}\text { It is shown that the } \\
\text { model accurately } \\
\text { predicts the message } \\
\text { delay for different relay } \\
\text { strategies for a number } \\
\text { of mobility models. This } \\
\text { model use two input } \\
\text { parameters: the number } \\
\text { of nodes and time until } \\
\text { two random mobiles } \\
\text { come within } \\
\text { communication range of } \\
\text { one another. }\end{array}$ & $\begin{array}{l}\text { A stochastic model } \\
\text { is introduced that } \\
\text { accurately models } \\
\text { the message delay } \\
\text { where nodes relay } \\
\text { messages and the } \\
\text { networks are } \\
\text { sparsely Populated. }\end{array}$ & Message Delay & $\begin{array}{l}\text { It is shown that the } \\
\text { model accurately } \\
\text { predicts the message } \\
\text { delay for different relay } \\
\text { strategies for a number } \\
\text { of mobility models. }\end{array}$ \\
\hline 2 & $\begin{array}{l}\text { On Minimizing } \\
\text { End-to-End Delay } \\
\text { With } \\
\text { Optimal Traffic } \\
\text { Partitioning[22] }\end{array}$ & 2006 & $\begin{array}{l}\text { An analytical framework } \\
\text { for the optimal } \\
\text { partitioning of real-time } \\
\text { multimedia traffic that } \\
\text { minimizes the total end- } \\
\text { to-end delay. }\end{array}$ & $\begin{array}{l}\text { It formulates } \\
\text { optimal traffic } \\
\text { partitioning as a } \\
\text { constrained } \\
\text { optimization } \\
\text { problem using } \\
\text { deterministic } \\
\text { network calculus } \\
\text { and derives its } \\
\text { closed-form } \\
\text { solution. }\end{array}$ & $\begin{array}{l}\text { End-to-end } \\
\text { delay using } \\
\text { optimal traffic } \\
\text { partitioning } \\
\text { scheme. }\end{array}$ & $\begin{array}{l}\text { By optimal traffic } \\
\text { partitioning, use a } \\
\text { minimum set of paths } \\
\text { while achieving } \\
\text { the minimum delay in } \\
\mathrm{O}(\mathrm{N}) \text { time. The } \\
\text { selected path set is } \\
\text { optimal in the sense } \\
\text { that adding any rejected } \\
\text { path to this set will only } \\
\text { increase the end-to-end } \\
\text { delay. }\end{array}$ \\
\hline 3 & $\begin{array}{l}\text { Routing Metrics } \\
\text { for Minimizing } \\
\text { End-to-End Delay } \\
\text { in Multi-Radio } \\
\text { Multi-Channel } \\
\text { Wireless } \\
\text { Networks[23] }\end{array}$ & 2013 & $\begin{array}{l}\text { The minimum expected } \\
\text { end-to-end delay (EED) } \\
\text { metric in a multi-radio } \\
\text { multi-channel (MRMC) } \\
\text { wireless network. }\end{array}$ & $\begin{array}{l}\text { Develop a generic } \\
\text { iterative approach } \\
\text { to compute the } \\
\text { multi-radio } \\
\text { achievable } \\
\text { bandwidth } \\
\text { (MRAB) for a } \\
\text { path. The MRAB } \\
\text { is combined with } \\
\text { the EED to form } \\
\text { the metric } \\
\text { weighted end-to- } \\
\text { end delay } \\
\text { (WEED). }\end{array}$ & $\begin{array}{l}\text { End-to-end } \\
\text { delay, Queuing } \\
\text { delay }\end{array}$ & $\begin{array}{l}\text { Designing link/path } \\
\text { metrics that can lead to } \\
\text { path selection with the } \\
\text { minimum end-to-end } \\
\text { delay and a high } \\
\text { network throughput in } \\
\text { the multi-radio multi- } \\
\text { channel wireless } \\
\text { network. }\end{array}$ \\
\hline 4 & $\begin{array}{l}\text { Fuzzy Controllers } \\
\text { Based Multipath } \\
\text { Routing Algorithm } \\
\text { in } \\
\text { MANET[24] }\end{array}$ & 2012 & $\begin{array}{l}\text { Here the work is done on } \\
\text { fuzzy logic based fuzzy } \\
\text { controller. }\end{array}$ & $\begin{array}{lr}\text { This } & \text { paper } \\
\text { introduces a fuzzy } \\
\text { controllers } & \text { based } \\
\text { multipath } & \text { routing } \\
\text { algorithm } & \text { in }\end{array}$ & $\begin{array}{l}\text { End-to-end } \\
\text { delay }\end{array}$ & $\begin{array}{l}\text { The key idea of the } \\
\text { proposed algorithm is } \\
\text { to construct the fuzzy } \\
\text { controllers with the } \\
\text { help to reduce the }\end{array}$ \\
\hline
\end{tabular}




\begin{tabular}{|c|c|c|c|c|c|c|}
\hline & & & & MANET (FMRM). & & $\begin{array}{l}\text { number of route } \\
\text { reconstruction. The } \\
\text { multiple routes were } \\
\text { efficiently selected, } \\
\text { which result in higher } \\
\text { packet delivery ratio, } \\
\text { lower routing packets } \\
\text { and lower end-to-end } \\
\text { delay. }\end{array}$ \\
\hline 5 & $\begin{array}{l}\text { MANET Link } \\
\text { Performance } \\
\text { Parameters using } \\
\text { Ant Colony } \\
\text { Optimization } \\
\text { Approach[25] }\end{array}$ & 2012 & $\begin{array}{l}\text { This paper presents a } \\
\text { new routing approach for } \\
\text { mobile ad hoc networks } \\
\text { (MANETs) which takes } \\
\text { into consideration the } \\
\text { Ant Colony Optimization } \\
\text { (ACO) technique in } \\
\text { conjunction with linear } \\
\text { programming approach } \\
\text { for minimizing the } \\
\text { overall delay in } \\
\text { networking environment. }\end{array}$ & $\begin{array}{l}\text { An Improved ant } \\
\text { routing algorithm } \\
\text { coupled with linear } \\
\text { programming } \\
\text { approach for } \\
\text { mobile ad-hoc } \\
\text { networks }\end{array}$ & Link delay & $\begin{array}{l}\text { The modified ant } \\
\text { algorithm has been able } \\
\text { to cope } \\
\text { with all dynamic } \\
\text { networks, in particular } \\
\text { its ability to improve } \\
\text { the link performance } \\
\text { after curtailing the link } \\
\text { delay to acceptable } \\
\text { limits in simulation } \\
\text { environment. }\end{array}$ \\
\hline 6 & $\begin{array}{l}\text { Minimum Delay } \\
\text { Routing Protocol } \\
\text { with Enhanced } \\
\text { Multimedia } \\
\text { Transmission over } \\
\text { Heterogeneous } \\
\text { MANETs[12] }\end{array}$ & 2012 & $\begin{array}{l}\text { Mathematical modeling } \\
\text { for QoS demands like } \\
\text { finding the path with } \\
\text { minimum delay among } \\
\text { the available paths taking } \\
\text { into consideration } \\
\text { geographic distance and } \\
\text { data rate. }\end{array}$ & $\begin{array}{lr}\text { This } & \text { paper } \\
\text { introduces } & \text { a } \\
\text { Minimum delay } \\
\text { routing protocol } \\
(\text { MDRP) used for } \\
\text { path selection. }\end{array}$ & $\begin{array}{l}\text { End-to-end } \\
\text { delay }\end{array}$ & $\begin{array}{l}\text { The performance of } \\
\text { MDRP is tested on two } \\
\text { different models one is } \\
\text { for Minimum delay } \\
\text { routing and other is for } \\
\text { Enhanced Multimedia } \\
\text { Transmission. }\end{array}$ \\
\hline 7 & $\begin{array}{l}\text { Interference-based } \\
\text { Topology Control } \\
\text { Algorithm for } \\
\text { Delay-constrained } \\
\text { Mobile Ad hoc } \\
\text { Networks[26] }\end{array}$ & 2012 & $\begin{array}{l}\text { In this paper, we focus } \\
\text { on the delay-constrained } \\
\text { topology control } \\
\text { problem, and take into } \\
\text { account delay and } \\
\text { interference jointly. }\end{array}$ & $\begin{array}{l}\text { Propose a cross- } \\
\text { layer distributed } \\
\text { algorithm called } \\
\text { interference-based } \\
\text { topology control } \\
\text { algorithm for } \\
\text { delay-constrained } \\
\text { (ITCD) MANETs } \\
\text { with Considering } \\
\text { interference } \\
\text { constraint and the } \\
\text { delay constraint. }\end{array}$ & $\begin{array}{l}\text { The } \\
\text { transmission } \\
\text { delay, } \\
\text { contention } \\
\text { delay and the } \\
\text { queuing delay } \\
\text { are taken into } \\
\text { account in the } \\
\text { Proposed } \\
\text { algorithm. }\end{array}$ & $\begin{array}{l}\text { When transmission } \\
\text { power is increased to } \\
\text { reduce the delay, which } \\
\text { increases the number of } \\
\text { neighbors covered by } \\
\text { the transmission range } \\
\text { and causes more } \\
\text { interference from other } \\
\text { active nodes in the } \\
\text { network. }\end{array}$ \\
\hline 8 & $\begin{array}{l}\text { Improving } \\
\text { Efficiency } \quad \text { of } \\
\text { MANET by } \\
\text { Reducing } \\
\text { Delay ruing } \\
\text { Hybrid } \\
\text { Algorithm[27] }\end{array}$ & 2013 & $\begin{array}{l}\text { In this paper an attempt } \\
\text { is made to improve the } \\
\text { quality of service QoS of } \\
\text { MANET by reducing } \\
\text { queuing delay in turn } \\
\text { increasing throughput by } \\
\text { proposing a new hybrid } \\
\text { algorithm. }\end{array}$ & $\begin{array}{l}\text { Sense the channel } \\
\text { using CSMA/CA. } \\
\text { By this we can } \\
\text { sense the traffic } \\
\text { over the channel. } \\
\text { Apply the hybrid } \\
\text { algorithm which is } \\
\text { the combination of } \\
\text { FCFS, SJF and } \\
\text { Priority algorithm } \\
\text { of scheduling. }\end{array}$ & $\begin{array}{l}\text { Queuing delay, } \\
\text { end-to-end } \\
\text { delay }\end{array}$ & $\begin{array}{l}\text { The algorithm is using } \\
\text { the CSMA/CA for } \\
\text { sensing the traffic level } \\
\text { of channel and the next } \\
\text { working of } \\
\text { algorithm depends } \\
\text { upon that traffic level. } \\
\text { This new developed } \\
\text { hybrid algorithm will } \\
\text { enhance the efficiency } \\
\text { in terms of reduced } \\
\text { end-to-end delay of } \\
\text { packet and } \\
\text { in turn throughput will }\end{array}$ \\
\hline
\end{tabular}




\begin{tabular}{|c|c|c|c|c|c|c|}
\hline & & & & & & be increased. \\
\hline 9 & $\begin{array}{l}\text { Adaptive packet } \\
\text { scheduling } \\
\text { technique } \\
\text { minimize to } \\
\text { packet delay time } \\
\text { in MANET by } \\
\text { maintaining } \\
\text { Queue for each } \\
\text { flow through FSM } \\
\text { Mechanism[28] }\end{array}$ & 2014 & $\begin{array}{l}\text { This paper, consider the } \\
\text { rate of data transmission, } \\
\text { the queue management, } \\
\text { routing path and } \\
\text { packet scheduling } \\
\text { technique. Queue is } \\
\text { maintained for each flow } \\
\text { and the delay } \\
\text { information of each flow } \\
\text { is maintained } \\
\text { accordingly. The } \\
\text { preprocessing of flow is } \\
\text { done up to the network } \\
\text { layer only. The source } \\
\text { and destination address } \\
\text { information is used for } \\
\text { separating the flow and } \\
\text { the transport layer } \\
\text { information } \\
\text { is not used. This } \\
\text { minimizes the delay in } \\
\text { the network. }\end{array}$ & $\begin{array}{l}\text { Finite State } \\
\text { Machine for Queue } \\
\text { Control and Finite } \\
\text { State Machine for } \\
\text { Transmission } \\
\text { Control }\end{array}$ & Packet delay & $\begin{array}{l}\text { In each node, queue is } \\
\text { maintained for each } \\
\text { flow and all are } \\
\text { identified based on the } \\
\text { source and destination } \\
\text { address of the } \\
\text { respective nodes. The } \\
\text { flow header is not } \\
\text { processed in all the } \\
\text { layers of the } \\
\text { intermediate nodes and } \\
\text { thus the delay in the } \\
\text { network is reduced, } \\
\text { where each flow has a } \\
\text { separate delay time } \\
\text { stamp. }\end{array}$ \\
\hline 10 & $\begin{array}{lr}\text { End-to-end } & \text { Delay } \\
\text { in Two Hop Relay } \\
\text { MANETs with } \\
\text { Limited Buffer[29] }\end{array}$ & 2015 & $\begin{array}{l}\text { This paper explore the } \\
\text { packet end-to-end delay } \\
\text { in a two-hop relay } \\
\text { MANET, where each } \\
\text { node is equipped with a } \\
\text { bounded and shared } \\
\text { relay-buffer for storing } \\
\text { and forwarding packets } \\
\text { of all other flows. In } \\
\text { addition a handshake } \\
\text { mechanism is added to } \\
\text { the } 2 \mathrm{HR} \text { routing } \\
\text { algorithm to avoid packet } \\
\text { loss. }\end{array}$ & $\begin{array}{l}\text { A handshake } \\
\text { mechanism is } \\
\text { introduced into the } \\
\text { traditional 2HR } \\
\text { algorithm, termed } \\
\text { as H2HR. With } \\
\text { H2HR, before each } \\
\text { source-to-relay } \\
\text { transmission, the } \\
\text { source node } \\
\text { initiates a } \\
\text { handshake with the } \\
\text { relay node to } \\
\text { confirm its relay- } \\
\text { buffer the relay } \\
\text { occupancy state, } \\
\text { once the } \\
\text { queue is full, the } \\
\text { source node } \\
\begin{array}{l}\text { cancels this } \\
\text { transmission. }\end{array}\end{array}$ & $\begin{array}{l}\text { packet queuing } \\
\text { delay and } \\
\text { delivery delay, }\end{array}$ & $\begin{array}{l}\text { A theoretical } \\
\text { framework has been } \\
\text { developed to fully } \\
\text { characterize } \\
\text { queuing processes of a } \\
\text { packet and obtain the } \\
\text { relay-buffer blocking } \\
\text { probability. }\end{array}$ \\
\hline
\end{tabular}

\section{CONCLUSION AND FUTURE WORK}

This paper presents a study on end-to-end delay in Mobile adHoc network. End-to-End delay is the combination of four type of delay i.e. processing delay, queuing delay, transmission delay and propagation delay. For each of these classes, several representative algorithms have reviewed. Each type of delay has unique dependency. Each kind of delay is examined with definition in this paper. It is possible to improve the End-to-end delay if any kind of delay can be improved either by reducing the flooding or by keeping queuing buffer empty. So if we can categories the type of the message and process each type of message separately than it is possible to improve queuing delay and transmission delay because than it has better possibility that the queue buffer is empty. On the other hand processing delay may remain same because determining and examining the packet header will changes very slightly to get the information about the type of message. 


\section{REFERENCES}

[1] Sanjay Kumar, Dr.Sudhir Kumar Rathi "A Review: Novel Protocol for Clumping in Mobile Ad hoc Networks" International Journal of Innovative Research in Computer and Communication Engineering Vol. 3, Issue 4, April 2015.

[2] Study of MANET: Characteristics, Challenges, Application and Security Attacks, Aarti, Dr. S. S. Tyagi International Journal of Advanced Research in Computer Science and Software Engineering Volume 3, Issue 5, May 2013.

[3] A Survey of Issues in Supporting QoS based Multicast Routing Protocols over MANETs, Dinesh Chander, Rajneesh Kumar International Journal of Computer Applications Volume 112 - No 13, February 2015.

[4] Ritu Verma, Dayashankar Singh A Review on Routing Protocol in MANETs International Journal of Advanced Research in Computer Science and Software Engineering, Volume 5, Issue 12, December 2015

[5] Proactive and Reactive Routing Protocols in Multihop Mobile Ad hoc Network Surendra H. Raut\#1, Hemant P. Ambulgekar*2 International Journal of Advanced Research in Computer Science and Software Engineering, Volume 3, Issue 4, April 2013

[6] Ruchita A. Kalamkar, Prof. Amit M. Sahu,"Improving the Performance of AODV by Minimizing Flooding Through High Power Routing Node." Vol. 3, Issue 4 IJIRCCE 2015

[7] Parimal Kumar Giri, "A Survey on Soft Computing Techniques for Multi-Constrained QoS Routing in MANET'IACSIT

[8] M. Shahram and B. Saeed, "Framework for providing QoS routing in MANETs," Seventh IEEE International Symposium on Computer Networks, 2006.

[9] A Survey of Routing Protocols that Support QoS in Mobile Ad Hoc Networks, Lei Chen and Wendi B. Heinzelman, IEEE Network 2007 IEEE.

[10] Routing in Ad-hoc Network with Quality of service Archna Rani , Dr. Manu Pratap Singh International Journal of Advanced Research in Computer Science and Software Engineering, Volume 4, Issue 2, February 2014.

[11] An Approach for Reducing the End-to-end Delay and Increasing Network Lifetime in Mobile Adhoc Networks, R. Asokan and A. M. Natarajan, International Journal of Information Technology Volume 4 Number 22007

[12] Khaja Anwar Ali Siddiqui, Yousuf Khan Afroz "Minimum Delay Routing Protocol with Enhanced Mutimedia Transmission over Heterogeneous MANETs" Trends in Innovative Computing 2012 - Intelligent Systems Design.

[13] M. Shahram and B. Saeed, "Framework for providing QoS routing in MANETs," Seventh IEEE International Symposium on Computer Networks, 2006.

[14] L. Chen and W. B. Heinzelman , "A Survey of Routing Protocols that support QoS in Mobile Ad Hoc Networks,"In IEEE magazine, December 2007.
[15] Parimal Kumar Giri, "A Survey on Soft Computing Techniques for Multi-Constrained QoS Routing in MANET", in 2012 IJCIT.

[16] QoS OVER HETEROGENEOUS NETWORKS, Mario Marchese, 2007

[17] G. Santhi and Alamelu Nachiappan," A SURVEY OF QOS ROUTING PROTOCOLS FOR MOBILE AD HOC NETWORKS” IJCSIT Vol.2, No.4, August 2010.

[18] K. Devarajan and V.Padmathilagam, "Optimized Path Evaluation For Mobile Ad Hoc Wireless Networks Using Enriched Protocols" International Journal of Applied Engineering Research 2015

[19] SOP: An Approach to Minimize Path Discovery Delay and Find Shortest Optimum Path V.Princy, Dr.P.Calduwel Newton, Special Issue Published in Int. Jnl. Of Advanced Networking and Applications (IJANA) 27th March 2015

[20] Prakash B. Khelage, Dr. Uttam D. Kolekar" Improving TCP Throughput Using Modified Packet Reordering Technique (MPRT) Over Manets" International Journal of advanced Computer Science and Applications Vol. 5, No. 8, 2014

[21] The Message Delay in Mobile Ad Hoc Networks, Robin Groenevelt a,b Philippe Nain a Ger Koole Preprint submitted to Elsevier Science,2005

[22] On Minimizing End-to-End Delay With Optimal Traffic Partitioning,, Shiwen Mao, Member, Shivendra S. Panwar, Senior Member, and Y. Thomas Hou, Senior Member, , IEEE TRANSACTIONS ON VEHICULAR TECHNOLOGY, VOL. 55, NO. 2, MARCH 2006

[23] Routing Metrics for Minimizing End-to-End Delay in Multiradio Multichannel Wireless Networks, Yu Cheng; Chi Zhou; Weihua Zhuang IEEE Transactions on Parallel and Distributed Systems 2013

[24] Fuzzy Controllers Based Pi, Shangchao; Sun, Baolin Multipath Routing Algorithm in MANET, 2012 Elsevier Science

[25] MANET Link Performance Parameters using Ant Colony Optimization Approach, Sarbjeet Kaur, Ravinder Singh Sawhney, Rajan Vohra 2012

[26] Interference-based Topology Control Algorithm for Delay-constrained Mobile Ad hoc Networks Yue Zhang; Fan Yan; Athanasios V. Vasilakos, IEEE Computer Society 2012.

[27] Improving Efficiency of MANET by Reducing Queuing Delay Using Hybrid Algorithm, Monika Sahu,Madhup Shrivastava,Sonika Matele,M. A. Rizvi, International Journal of Advanced Research in Computer Science (IJARCS) 2013.

[28] Adaptive packet scheduling technique to minimize the packet delay time in MANET by maintaining a Queue for each flow through FSM Mechanism, K. Sasikala, Dr. R. S. D. Wahidabanu, Journal of Convergence Information Technology(JCIT), 2014

[29] End-to-end delay in two hop relay MANETs with limited buffer Jia Liu, Yang Xu, Xiaohong Jiang , WWW.arxiv.org > cs 2015. 